Uluslararası Mühendislik

Cilt/Volume:11 Sayı/Issue:1 Ocak/January 2019

Araştırma Makalesi / Research Article

\title{
Cost Optimization of Colored Gypsum Composites
}

\author{
Sadık Alper Yıldızel*1 iD, Gökhan Kaplan ${ }^{2}$ \\ ${ }^{1}$ Karamanoğlu Mehmetbey Üniversitesi, Mühendislik Fakültesi, Inşaat Mühendisliği Bölümü, 70100, Karaman, TURKEY \\ ${ }^{2}$ Kastamonu Üniversitesi,Mühendislik ve Mimarlık Fakültesi, İş̧aat Mühendisliği Bölümü, 37100, Kastamonu, TURKEY
}

Başvuru/Received: 16/03/2018

Kabul/Accepted: 04/12/2018

Son Versiyon/Final Version: 31/01/2019

\begin{abstract}
Lately, gypsum composites as decorative and construction elements have been widely used for many building types due to their certain architectonic styles. Decorative gypsum composites are not very durable and stable when compared to the other composites; therefore, they need to be rehabilitated in short periods. To meet the increasing demand in the sustainability of these types of the composite, many researches have been conducted for improving its properties with the minimum cost. The aim of this study was to obtain the optimum cost of the colored gypsum composites with the improved mechanical properties. Glass fiber reinforced, silica and expanded perlite reinforced gypsum composites were colored with the addition of brown, yellow, black and red pigments. The mechanical properties such as compressive strength and freeze thaw (F-T) resistance of the mixes were also examined. A cost optimization analyze were performed based on the experimental test results. Results revealed that the usage and the cost of the color pigment added gypsum composites could be primarily optimized.
\end{abstract}

\section{Key Words}

“Color pigments, gypsum, gypsum composites, cost optimization” 


\section{INTRODUCTION}

Gypsum and gypsum composites have been widely used for many purposes in construction industry due their characteristic fire resistance, thermal and sound insulation properties (Gazineu, Santos, Hazin, Vasconcelos, \& Dantas, 2011; Gencel et al., 2014; Gutiérrez-González, Gadea, Rodríguez, Blanco-Varela, \& Calderón, 2012; Gutiérrez-González, Gadea, Rodríguez, Junco, \& Calderón, 2012; Heim \& Clarke, 2004; Li, Wu, \& Chen, 2011; Serhat Başpinar \& Kahraman, 2011; Vimmrová, Keppert, Svoboda, \& Černý, 2011). Different materials can be added to gypsum-based composites to improve their mechanical properties (Murat \& Attari, 1991). Also, fibers or aggregates in different sieve size can be added to enhance their mechanical behaviors (Cantwell \& Morton, 1991; Eve et al., 2002; Yu \& Brouwers, 2012). Fibers such as carbon fiber, glass fiber, polypropylene fiber have been widely preferred for the latest relevant studies to improve mechanical properties like flexural strength (Çolak, 2006; Mohandesi, Sangghaleh, Nazari, \& Pourjavad, 2011; Yu Fei Wu, 2004).

Gypsum can be evaluated as the softest binder, since its structure may be severely damaged by hydration reactions. To prevent the solution of gypsum in water, gypsum can be reinforced with a water impermeable material (Camarini \& De Milito, 2011). The various studies focused on the addition of rice husk, silica fume, iron oxide, blast furnace slag and blast furnace dust to improve water resistant properties of gypsum composites (Khalil, Tawfik, Hegazy, \& El-Shahat, 2014; Mazloom, Ramezanianpour, \& Brooks, 2004; Yakovlev, Khozin, Polyanskikh, \& Keriene, 2014; Yakovlev, Polyanskikh, Fedorova, Gordina, \& Buryanov, 2015).

As mentioned above, gypsum is reinforced with various types of fiber to increase its mechanical properties like fracture energy and toughness, since it is a very brittle material (Ali \& Grimer, 1969; Del Río Merino \& Hernández Olivares, 2000; Eve et al., 2002; García Santos, 2009; Hernández-Olivares, Oteiza, \& de Villanueva, 1992). These fibers can be classified into two group as natural and manufactured origin. One of the manufactured fibers used widely for producing gypsum composites are glass fibers (Flores Medina \& Barbero-Barrera, 2017). Glass fiber reinforced gypsum composites are not very old and traditional, especially to produce precast gypsum panels. For this reason, conventional design criteria are not entirely applicable. Lately, many comprehensive researches have been conducted to gain better understanding of its structural behavior (Liu, Wu, \& Jiang, 2008; Prasad, Menon, \& Janardhana, 2008; Sreenivasa, Menon, \& Prasad, 2008; Y F Wu \& Dare, 2006; Yu Fei Wu, 2004; Zhang, Qiao, Wu, \& Li, 2012). In-situ and none-destructive test was performed with the aim of developing design rules for the precast gypsum-based composites. One of the research topic in these research is the limitation of the shrinkage effect of the panels (Nassif, Yoshitake, \& Allam, 2014; Terai \& Minami, 2012).

Perlite is originated from the alumino-siliceous volcanic rock. When heated, it gets expanded and reached a form of cellular material with low density (Różycka \& Pichór, 2016). Expanded perlite has excellent heat and acoustic insulating properties depending on its porous microstructure (Sodeyama, Sakka, Kamino, \& Seki, 1999). The perlite-based composite becomes lately, one of the most popular mineral filler due to its lightweight structure (Jedidi, Benjeddou, \& Soussi, 2015; Lanzón \& García-Ruiz, 2008; Sun \& Wang, 2015). As of 2012, global perlite registered perlite production is 2.6 million tons per year. China leads the perlite production and is followed by Greece, the USA, and Turkey (Briga-Sá et al., 2013). In concrete production, expanded perlite is used as an aggregate replacement material at required ratios to obtain aimed mechanical properties. The research results show that some mechanical properties like compressive strength and modulus of elasticity decrease with the increase expanded perlite amount in mix designs. However, water absorption rate and the thermal conductivity decreased with higher expanded content (Sengul, Azizi, Karaosmanoglu, \& Tasdemir, 2011).

Colored gypsum composite is an architectural design element which is produced as a response to the unaesthetic outlook of traditional concrete. Pigments are used to obtain a colored composite. Pigments provide an aesthetical look; however, they bring some physical disadvantages such as efflorescence and low processability for composite materials (Jang, Kang, \& So, 2014). Pigments are widely preferred for composite applications for obtaining colored surface (Greenstein \& Lewis, 1998). Hematite (red, orange, purple), goethite (yellow), lepidocrocite (brown), calcite and dolomite (white), celadonite and malachite (green), quartz (white and translucent) and many others have been used as pigments since the antique ages. On the other hand, litharge (red), massicot (yellow), red lead (orange), chrome oxide (green) have been used as synthetic pigments (Fernández Rodríguez \& Fernández Fernández, 2005; Mármol et al., 2010).

Pigments are a powdered material with finer grains compared to cement. Pigments used with cement-based composites are sieved using sieve opening No 200. Thus, it is expected for the mixtures water/pigment ratio to be higher for a specific thickness. Nevertheless, the pigment's size and surface properties also have an impact on the water/pigment ratio. Pigment's water requirement and dosage are among the essential factors predicting its color durability. Pigments also have an impact on the shrinkage behavior of the composite (Lee, Lee, \& Yu, 2003; Ravi Kumar, Kumar, Prashanth, \& Reddy, 2012). Properties such as setting time, lightfastness, durability, mechanical properties, heat resistance and soluble salt content gain importance in colored concrete.

Numerous mathematical linear and nonlinear optimization methods have been selected to solve the optimization problem (Fereig, 1994; Pellegrino, 1990). In some applications, local optimum values are searched by following the path of the local gradient. Other methodologies include the application of the first and second order boundaries of the condition to find a local minimum base by 
solving nonlinear equations. These methods can be inefficient due to heavy calculations (Kaveh, Maniat, \& Arab Naeini, 2016). Lately, alternative methods have become popular among the researchers. Design of experiments is widely recognized as a procedure to plan and define the boundaries for performing experimental trials. Academics have been increasingly replaced the traditional time and money consuming physical studies with faster and cheaper computer algorithms (Garud, Karimi, \& Kraft, 2017).

This experimental study is significant due to the fact there are very limited researches on the cost optimization of colored gypsum composites. And there exists no proved relationship between the color pigments and the cost of the gypsum-based composites.

\section{MATERIALS AND EXPERIMENTAL STUDIES}

\subsection{Gypsum}

Gypsum mixes according to the EN 13279-1 (BS EN 13279-1:2008, 2009) was used within the scope of this research. The properties of the gypsum were presented in Table 1.

Table 1. Properties of the Gypsum

\begin{tabular}{ll}
\hline Chemical composition & $\mathrm{CaSO} 4 . \mathrm{xH} 2 \mathrm{O}(\mathrm{x}=0,1 / 2,2)$ \\
\hline Harmful substances (Gefahrstoffverordnung) & Concentration, Max value: $6 \mathrm{mg} / \mathrm{m}^{3}$ \\
Compressive strength (Mpa) & 2.7 \\
Flexural strength $(\mathrm{Mpa})$ & 1.2 \\
Dry density $\left(\mathrm{kg} / \mathrm{m}^{3}\right)$ & $600-1000$ \\
Workability time (min) & $70-100$ \\
Final setting time (min) & 140 \\
\hline
\end{tabular}

\subsection{Silica Sand}

Silica sand having the AFS 30 to 35 (according to the DIN factor calculations) was used, the properties of the sand listed in Table 2 and Fig. 1.

Table 2. Properties of the Silica Sand

\begin{tabular}{ll}
\hline Clay Content $(\%)$ & $0.6-0.8$ \\
\hline Specific Weight & 2.68 \\
$\mathrm{AFS}$ value & 34.6 \\
$\% \mathrm{SiO}_{2}$ & 98.60 \\
$\% \mathrm{Fe}_{2} \mathrm{O}_{3}$ & 0.13 \\
$\% \mathrm{MgO}$ & 0.03 \\
$\% \mathrm{CaO}$ & 0.01 \\
$\% \mathrm{~K}_{2} \mathrm{O}$ & 0.09 \\
$\% \mathrm{Na}_{2} \mathrm{O}$ & 0.02 \\
$\% \mathrm{Al}_{2} \mathrm{O}_{3}$ & 1.12 \\
\hline
\end{tabular}

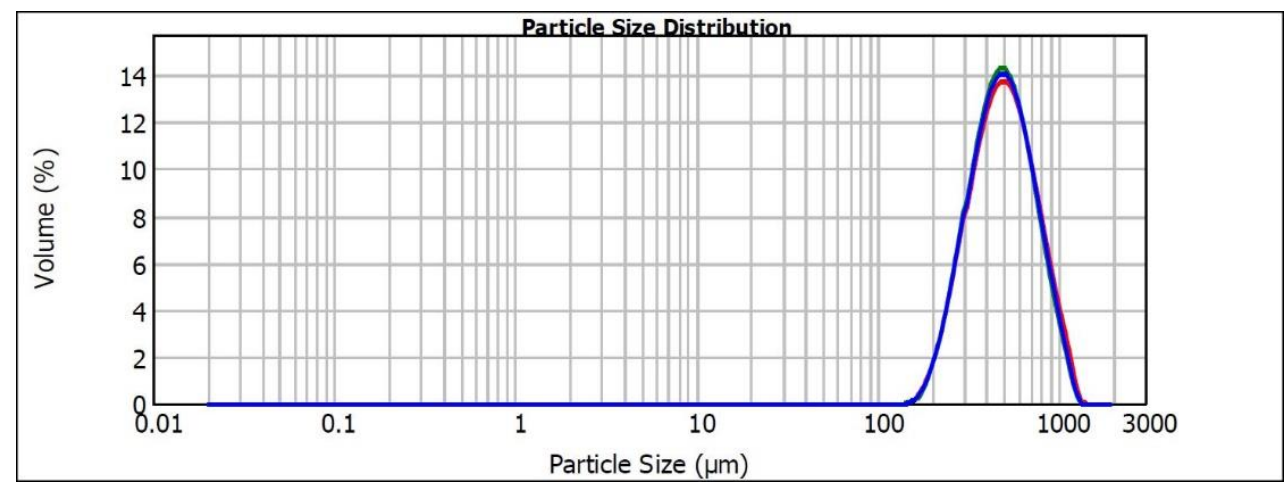

Figure 1. Particle size distribution of Silica Sand

\subsection{Expanded Perlite}

Commercial expanded perlite was used for this study. The particle size distribution and the properties of this material were given in Fig. 2 and Table 3, respectively. 


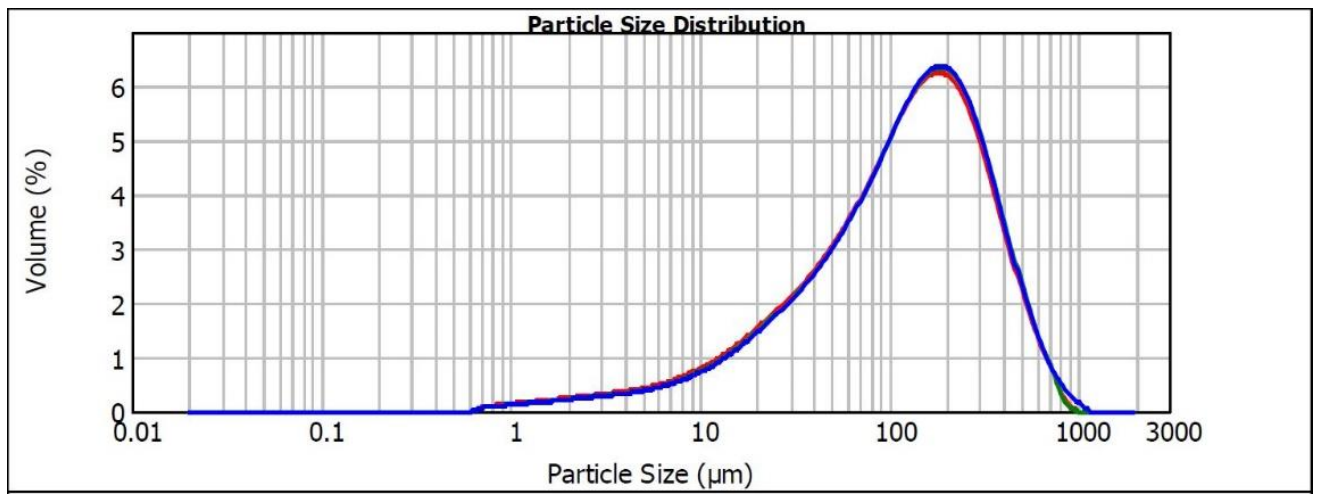

Figure 2. Particle size distribution of Expanded Perlite

Table 3. Properties of the Expanded Perlite

\begin{tabular}{ll}
\hline Chemical composition & \\
\hline$\% \mathrm{SiO}_{2}$ & 72 \\
$\% \mathrm{Al}_{2} \mathrm{O}_{3}$ & 12 \\
$\% \mathrm{~K}_{2} \mathrm{O}$ & 4.1 \\
$\% \mathrm{Na}_{2} \mathrm{O}$ & 3.4 \\
$\% \mathrm{MgO}_{\mathrm{Ne}}$ & 0.2 \\
$\% \mathrm{Fe}_{3}$ & 2.5 \\
$\% \mathrm{CaO}$ & 3 \\
\hline
\end{tabular}

\subsection{Alkali Resistant Glass Fiber}

Alkali resistant glass fiber with $20 \mu \mathrm{m}$ diameter and $12 \mathrm{~mm}$ length were used the properties of the glass fiber were given in Table 4. The fibers were sprayed with the ration of $1 \mathrm{wt} . \%$ and $1.5 \mathrm{wt} . \%$.

Table 4. Properties of the Alkali Resistant Glass Fiber

\begin{tabular}{ll}
\hline Ultimate strength, bending (MOR, MPa) & $20-28$ \\
\hline Elastic limit, bending (LOP, MPa) & $7-11$ \\
Ultimate strength, tensile (MOR, MPa) & $8-11$ \\
Elastic limit, tensile (LOP, MPa) & $5-7$ \\
Compressive Strength (Mpa) & $50-80$ \\
Elastic Modulus (GPa) & $10-20$ \\
Dry density $\left(\mathrm{t} / \mathrm{m}^{3}\right)$ & $1.9-2.1$ \\
\hline
\end{tabular}

\subsection{Preparation of the Gypsum Composites}

Mix proportions and experimental set of the composite are given in Table 5. The reference mix was composed of glass fiber and gypsum. The silica sand was replaced by expanded perlite by $5 \%, 10 \%$ and $15 \%$ by weight of the silica sand. The gypsum mixtures containing silica sand and expanded perlite were mixed in a mixer for 5 minutes to obtain a homogenous dry mixture. Water and glass fibers in $12 \mathrm{~mm}$ length were added just before the spraying process and mixed for 5 minutes again. The glass fiber was used at the volumes of $1 \%$ and $1.5 \%$ in the mixture. Polycarboxylate based third generation water reducer was used as the chemical agent. The water used during the experimental works was potable water and at $21 \mathrm{C}^{\circ}$. The static consistency of the glass fiber added mixes were measured as per the requirements of the EN 1170-1 (Fig. 3 and 4). This slump test was performed with a cylindrical funnel (height:60mm, inner radius: $57 \mathrm{~mm}$, outer radius:65mm). Two different molds as $40 \mathrm{x} 40 \mathrm{x} 40 \mathrm{~mm}$ and $160 \mathrm{x} 40$ x $40 \mathrm{~mm}$ were prepared for the mechanical tests. All test specimens were kept at the molds for 24 hours at room temperature. The compressive and flexural strength of the specimens were measured complying the EN 13279-2 for 1 day, 7 days and 28 days (BS EN 13279-1:2008, 2009). 
Table 5. Mixture Designs

\begin{tabular}{lllllll}
\hline $\begin{array}{l}\text { Mixture } \\
\text { Code }\end{array}$ & $\begin{array}{l}\text { Silica } \\
\text { Sand (kg) }\end{array}$ & $\begin{array}{l}\text { Expanded } \\
\text { Perlite }\end{array}$ & $\begin{array}{l}\text { Fiber } \\
(\mathbf{\%})\end{array}$ & $\begin{array}{l}\text { Gypsum } \\
(\mathbf{k g})\end{array}$ & $\begin{array}{l}\text { Pigment } \\
(\mathbf{g})\end{array}$ & $\begin{array}{l}\text { Mix/Water } \\
(\mathbf{g} / \mathbf{m l})\end{array}$ \\
\hline $\mathrm{R}_{1}$ & 0 & 0 & 1 & 50 & 1.250 & \\
$\mathrm{R}_{2}$ & 0 & 0 & 1.5 & 50 & 1.250 & \\
$\mathrm{~A}_{1}$ & 25 & 0 & 1 & 25 & 1.250 & \\
$\mathrm{~A}_{2}$ & 25 & 0 & 1.5 & 25 & 1.250 & \\
$\mathrm{~B}_{1}$ & 23.75 & 1.25 & 1 & 25 & 1.250 & \\
$\mathrm{~B}_{2}$ & 23.75 & 1.25 & 1.5 & 25 & 1.250 & 1.6 \\
$\mathrm{C}_{1}$ & 22.5 & 2.5 & 1 & 25 & 1.250 & \\
$\mathrm{C}_{2}$ & 22.5 & 2.5 & 1.5 & 25 & 1.250 & \\
$\mathrm{D}_{1}$ & 21.25 & 3.75 & 1 & 25 & 1.250 & \\
$\mathrm{D}_{2}$ & 21.25 & 3.75 & 1.5 & 25 & 1.250 & \\
\hline \multicolumn{5}{l}{ Static viscosity (TS EN 1170-1), circle number } \\
\hline
\end{tabular}

\subsection{Mechanical Properties}

Experimental test results are given in Table 6. Density values decrease when the expanded perlite content increases.

Table 6. Mechanical Properties of the Gypsum Composite

\begin{tabular}{llllllllr}
\hline $\begin{array}{l}\text { Mixture } \\
\text { Code }\end{array}$ & $\begin{array}{l}\text { Density } \\
\left(\mathbf{g} / \mathbf{c m}^{\mathbf{3}}\right)\end{array}$ & $\begin{array}{l}\text { Water } \\
\text { absorption }(\%)\end{array}$ & $\begin{array}{l}\text { Bending } \\
\text { (Mpa) }\end{array}$ & Strength & $\begin{array}{l}\text { Compressive } \\
\text { (Mpa) }\end{array}$ & Strength \\
\hline & & & $\begin{array}{l}1 \text {-day } \\
\text { day }\end{array}$ & 7 -day & $28-$ & 1-day & 7 -day & $28-$ \\
& & & & & & day & & \\
$\mathrm{R}_{1}$ & 1.12 & 39.21 & 1.62 & 1.73 & 1.92 & 2.80 & 3.10 & 3.41 \\
$\mathrm{R}_{2}$ & 1.19 & 40.13 & 1.69 & 1.84 & 2.01 & 2.88 & 3.19 & 3.52 \\
$\mathrm{~A}_{1}$ & 1.92 & 37.13 & 1.65 & 1.74 & 1.93 & 3.12 & 3.24 & 3.57 \\
$\mathrm{~A}_{2}$ & 2.01 & 37.41 & 1.75 & 1.86 & 2.07 & 3.26 & 3.32 & 3.61 \\
$\mathrm{~B}_{1}$ & 1.79 & 39.41 & 1.53 & 1.61 & 1.88 & 2.99 & 3.12 & 3.39 \\
$\mathrm{~B}_{2}$ & 1.82 & 40.10 & 1.57 & 1.69 & 1.94 & 3.00 & 3.15 & 3.46 \\
$\mathrm{C}_{1}$ & 1.70 & 40.17 & 1.50 & 1.57 & 1.81 & 2.83 & 3.02 & 3.31 \\
$\mathrm{C}_{2}$ & 1.72 & 40.62 & 1.52 & 1.61 & 1.89 & 2.91 & 3.09 & 3.37 \\
$\mathrm{D}_{1}$ & 1.67 & 41.64 & 1.43 & 1.51 & 1.68 & 2.79 & 2.98 & 3.27 \\
$\mathrm{D}_{2}$ & 1.69 & 42.03 & 1.50 & 1.56 & 1.74 & 2.86 & 3.01 & 3.30 \\
\hline
\end{tabular}

\subsection{Cost Analysis and the Optimization}

Cost optimization of the pigments becomes a very important factor depending on its high costs compared the other ingredients of the mortar. The full factorial experimental design was chosen due to the few test quantities. This design method is a good choice when the resources are limited. This experiment also allows the user to examine the effect of each factor on the response data. This study does not comprise the cross-sectional optimization of the final products. Further development and implementation of this approach can be considered for further researchers. The unit cost of the ingredients of the composites is given in Table 7 .

Table 7. Unit Cost of the materials

\begin{tabular}{ll}
\hline Material & Unit price (USD / kg) \\
\hline Gypsum & 1 \\
Silica sand & 0.21 \\
Expanded perlite & 2.5 \\
Glass fiber & 6 \\
Brown pigment & 3.06 \\
Yellow pigment & 5.13 \\
Black pigment & 2.71 \\
Red pigment & 3.05 \\
\hline
\end{tabular}

The production cost of the glass fiber reinforced, and colored concrete can be varied according to the glass fiber and pigment content. The cost of the mixtures is presented in Table 8 . 
Table 8. Cost of Colored Gypsum Composites

\begin{tabular}{|c|c|c|}
\hline Mixture Code & Pigment & Cost (USD / kg) \\
\hline \multirow{5}{*}{$\mathrm{R}_{1}$} & Reference & 53.00 \\
\hline & Brown & 53.31 \\
\hline & Yellow & 53.51 \\
\hline & Black & 53.27 \\
\hline & Red & 53.30 \\
\hline \multirow[t]{5}{*}{$\mathrm{R}_{2}$} & Reference & 54.50 \\
\hline & Brown & 54.81 \\
\hline & Yellow & 55.01 \\
\hline & Black & 54.77 \\
\hline & Red & 54.80 \\
\hline \multirow[t]{5}{*}{$\mathrm{A}_{1}$} & Reference & 31.75 \\
\hline & Brown & 31.90 \\
\hline & Yellow & 32.01 \\
\hline & Black & 31.89 \\
\hline & Red & 31.90 \\
\hline \multirow[t]{5}{*}{$\mathrm{A}_{2}$} & Reference & 32.50 \\
\hline & Brown & 32.65 \\
\hline & Yellow & 32.76 \\
\hline & Black & 32.64 \\
\hline & Red & 32.65 \\
\hline \multirow[t]{5}{*}{$\mathrm{B}_{1}$} & Reference & 34.61 \\
\hline & Brown & 34.77 \\
\hline & Yellow & 34.87 \\
\hline & Black & 34.75 \\
\hline & Red & 34.76 \\
\hline \multirow[t]{5}{*}{$\mathrm{B}_{2}$} & Reference & 35.36 \\
\hline & Brown & 35.52 \\
\hline & Yellow & 35.62 \\
\hline & Black & 35.50 \\
\hline & Red & 35.51 \\
\hline \multirow[t]{5}{*}{$\mathrm{C}_{1}$} & Reference & 37.48 \\
\hline & Brown & 37.63 \\
\hline & Yellow & 37.73 \\
\hline & Black & 37.61 \\
\hline & Red & 37.63 \\
\hline \multirow[t]{5}{*}{$\mathrm{C}_{2}$} & Reference & 38.23 \\
\hline & Brown & 38.38 \\
\hline & Yellow & 38.48 \\
\hline & Black & 38.36 \\
\hline & Red & 38.38 \\
\hline \multirow[t]{5}{*}{$\mathrm{D}_{1}$} & Reference & 40.34 \\
\hline & Brown & 40.49 \\
\hline & Yellow & 40.59 \\
\hline & Black & 40.47 \\
\hline & Red & 40.49 \\
\hline \multirow[t]{5}{*}{$\mathrm{D}_{2}$} & Reference & 41.09 \\
\hline & Brown & 41.24 \\
\hline & Yellow & 41.34 \\
\hline & Black & 41.22 \\
\hline & Red & 41.24 \\
\hline
\end{tabular}

Four functions were used during the optimization studies. Models include the optimization of gypsum composites according to the cost, unit weight, compressive strength and bending strength values. The responses and objective functions are listed as in Table 9 . 
Table 9. Optimization Functions

\begin{tabular}{ll}
\hline Response & Objective function \\
\hline Cost & Minimum \\
Unit weight & Minimum \\
Compressive strength (28-day) & Maximum \\
Bending strength (28-day) & Maximum \\
\hline
\end{tabular}

\section{RESULTS AND DISCUSSION}

The pigment type and the composite cost relation is presented in Fig. 3. Generally, gypsum composite cost increases with the addition of color pigments. It can be seen from Fig. 3 that the maximum cost was obtained with the use of yellow pigment.

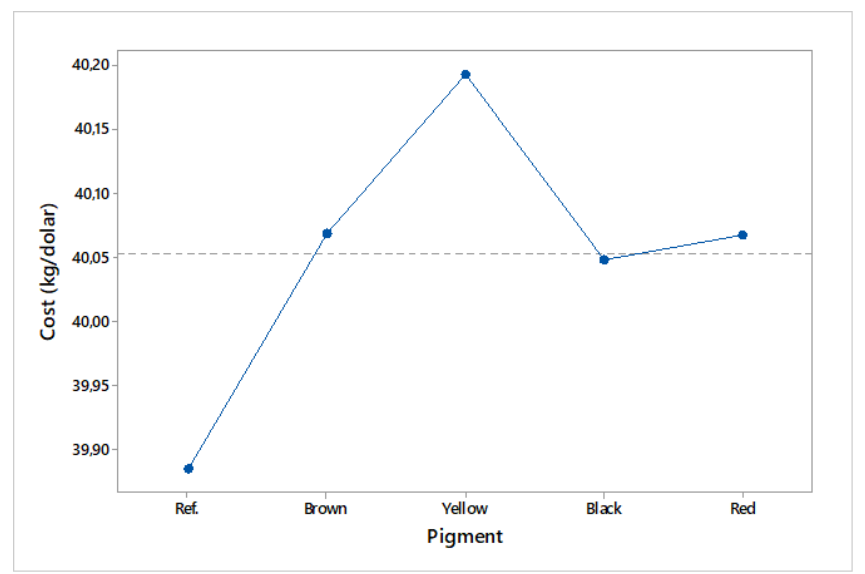

Figure 3. Color Pigment and Composite Cost Relation

The cost of the expanded perlite added mixtures decreased compared to the reference mixes. The cost effect of expanded perlite on the composite mixes are given in Fig. 4. However, cost increases existed when the expanded perlite used with other mix groups.

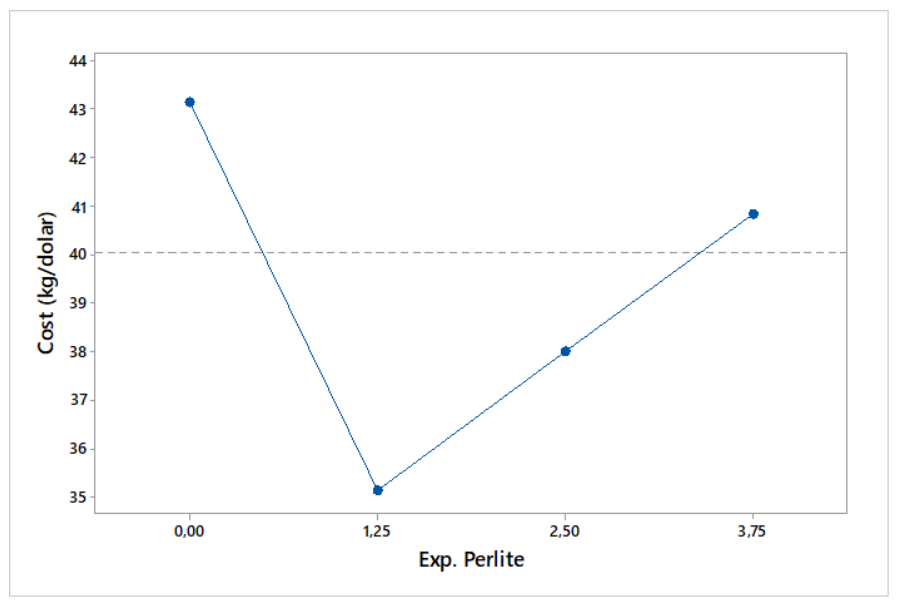

Figure 4. Expanded Perlite and Composite Cost Relation

Glass fiber addition into the mixes increased the composite costs, as well. But this rise was within the limit of 0.90 Usd per mixes. The fiber content and cost relation can be seen in Fig. 5. 


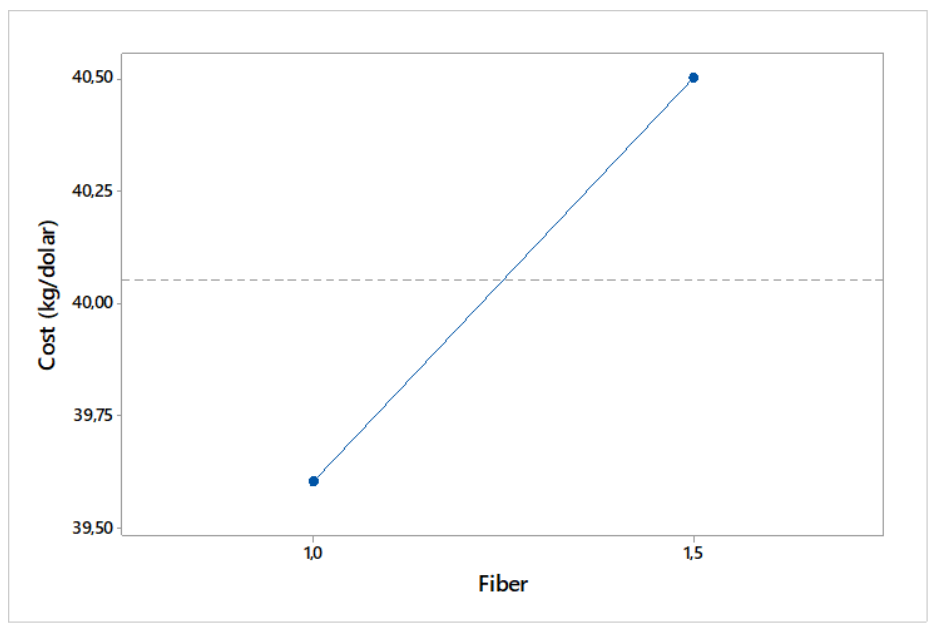

Figure 5. Glass Fiber and Composite Cost Relation

The most suitable mix according to the objective functions is given in Table 10 . This mix includes $23.75 \mathrm{~kg}$ of silica sand, $1.25 \mathrm{~kg}$ of expanded perlite, $1.5 \%$ glass fiber, $25 \mathrm{~kg}$ of gypsum and the red color pigment.

Table 10. Suitable Mix (SM) Design Content

\begin{tabular}{lllll}
\hline $\begin{array}{l}\text { Silica } \\
\text { Sand }(\mathbf{k g})\end{array}$ & $\begin{array}{l}\text { Expanded } \\
\text { perlite }(\mathbf{k g})\end{array}$ & $\begin{array}{l}\text { Glass } \\
\text { fiber }(\%)\end{array}$ & Gypsum(kg) & Pigment type \\
\hline 23.75 & 1.25 & 1.5 & 25 & Red \\
\hline
\end{tabular}

Mechanical properties of the most suitable mix are given in Table 11. When the ingredients are added as seen in Table 10, the cost and mechanical properties of the composite can be as following Table 11.

Table 11. SM Cost

\begin{tabular}{|c|c|c|c|c|}
\hline Cost (Usd) & $\begin{array}{l}\text { Unit } \\
\left(t / m^{3}\right)\end{array}$ & weight & $\begin{array}{l}\text { Compressive strength } \\
\text { (28-day, Мра) }\end{array}$ & $\begin{array}{l}\text { Bending strength } \\
\text { (28-day, Мpa) }\end{array}$ \\
\hline 35.51 & 1.82 & & 3.46 & 1.94 \\
\hline
\end{tabular}

\section{CONCLUSIONS}

Making accurate decisions at the very early stages of a project can assist researches to obtain aimed design solutions. In this study, cost optimization of glass fiber reinforced, color pigment, silica sand and expanded perlite added gypsum composites is presented The objective function consists of the material cost involved in the production of the composite, compressive strength, bending strength and the unit weight. A design of experiment study was conducted to analyze the effect of each ingredient on the optimum design.

A cost optimization model for colored gypsum composite has been improved in this paper. As the scope and the details of the ingredient material expand, the outcomes become more reliable for future studies. Moreover, human based aspects of the new architectural design still need further researches.

\section{REFERENCES}

Ali, M. A., \& Grimer, F. J. (1969). Mechanical properties of glass fibre-reinforced gypsum. Journal of Materials Science. https://doi.org/10.1007/BF00549703

Briga-Sá, A., Nascimento, D., Teixeira, N., Pinto, J., Caldeira, F., Varum, H., \& Paiva, A. (2013). Textile waste as an alternative thermal insulation building material solution. Construction and Building Materials. https://doi.org/10.1016/j.conbuildmat.2012.08.037

BS EN 13279-1:2008. (2009). Gypsum binders and gypsum plasters - Part 1: Definitions and requirements. British Standard.

Camarini, G., \& De Milito, J. A. (2011). Gypsum hemihydrate-cement blends to improve renderings durability. Construction and Building Materials. https://doi.org/10.1016/j.conbuildmat.2011.04.048 
Çolak, A. (2006). Physical and mechanical properties of polymer-plaster composites. Materials Letters. https://doi.org/10.1016/j.matlet.2005.12.062.

Del Río Merino, M., \& Hernández Olivares, F. (2000). Reinforced plaster by means of the synergic action between concrete additives (superfluidifiers, fluidifiers and airing-plasticizers) and E glass fibres. Materiales de Construccion.

Eve, S., Gomina, M., Gmouh, A., Samdi, A., Moussa, R., \& Orange, G. (2002). Microstructural and mechanical behaviour of polyamide fibre-reinforced plaster composites. Journal of the European Ceramic Society. https://doi.org/10.1016/S0955$\underline{\text { 2219(02)00014-6 }}$

Fereig, S. M. (1994). An application of linear programming to bridge design with standard prestressed girders. Computers and Structures. https://doi.org/10.1016/0045-7949(94)90016-7

Fernández Rodríguez, J. M., \& Fernández Fernández, J. A. (2005). Application of the second derivative of the Kubelka-Munk function to the semiquantitative analysis of Roman paintings. Color Research and Application. https://doi.org/10.1002/col.20157

Flores Medina, N., \& Barbero-Barrera, M. M. (2017). Mechanical and physical enhancement of gypsum composites through a synergic work of polypropylene fiber and recycled isostatic graphite filler. Construction and Building Materials. https://doi.org/10.1016/j.conbuildmat.2016.11.073.

García Santos, A. (2009). Escayola reforzada con fibras de polipropileno y aligerada con perlas de poliestireno expandido. Materiales de Construcción. https://doi.org/10.3989/mc.2009.41107

Garud, S. S., Karimi, I. A., \& Kraft, M. (2017). Design of computer experiments: A review. Computers and Chemical Engineering. https://doi.org/10.1016/j.compchemeng.2017.05.010

Gazineu, M. H. P., Santos, V. A. Dos, Hazin, C. A., Vasconcelos, W. E. De, \& Dantas, C. C. (2011). Production of polymer-plaster composite by gamma irradiation. In Progress in Nuclear Energy. https://doi.org/10.1016/j.pnucene.2011.06.014

Gencel, O., Del Coz Diaz, J. J., Sutcu, M., Koksal, F., Alvarez Rabanal, F. P., Martinez-Barrera, G., \& Brostow, W. (2014). Properties of gypsum composites containing vermiculite and polypropylene fibers: Numerical and experimental results. Energy and Buildings. https://doi.org/10.1016/j.enbuild.2013.11.047

Greenstein, L. M., \& Lewis, P. E. (1998). Pigment Handbook. Part.

Gutiérrez-González, S., Gadea, J., Rodríguez, A., Blanco-Varela, M. T., \& Calderón, V. (2012). Compatibility between gypsum and polyamide powder waste to produce lightweight plaster with enhanced thermal properties. Construction and Building Materials. https://doi.org/10.1016/j.conbuildmat.2012.02.061

Gutiérrez-González, S., Gadea, J., Rodríguez, A., Junco, C., \& Calderón, V. (2012). Lightweight plaster materials with enhanced thermal properties made with polyurethane foam wastes. Construction and Building Materials. https://doi.org/10.1016/j.conbuildmat.2011.10.055

Heim, D., \& Clarke, J. A. (2004). Numerical modelling and thermal simulation of PCM-gypsum composites with ESP-r. In Energy and Buildings. https://doi.org/10.1016/j.enbuild.2004.01.004

Hernández-Olivares, F., Oteiza, I., \& de Villanueva, L. (1992). Experimental analysis of toughness and modulus of rupture increase of sisal short fiber reinforced hemihydrated gypsum. Composite Structures. https://doi.org/10.1016/0263-8223(92)90001-S

Jang, H. seok, Kang, H. seon, \& So, S. young. (2014). Color expression characteristics and physical properties of colored mortar using ground granulated blast furnace slag and White cement

Jedidi, M., Benjeddou, O., \& Soussi, C. (2015). Effect of expanded perlite aggregate dosage on properties of lightweight concrete. Jordan Journal of Civil Engineering. https://doi.org/10.1016/j.jmatprotec.2007.10.052

Kaveh, A., Maniat, M., \& Arab Naeini, M. (2016). Cost optimum design of post-tensioned concrete bridges using a modified colliding bodies optimization algorithm. Advances in Engineering Software. https://doi.org/10.1016/j.advengsoft.2016.03.003

Khalil, A. A., Tawfik, A., Hegazy, A. A., \& El-Shahat, M. F. (2014). Effect of some waste additives on the physical and mechanical properties of gypsum plaster composites. Construction and Building Materials. https://doi.org/10.1016/j.conbuildmat.2014.06.081 
Lanzón, M., \& García-Ruiz, P. A. (2008). Lightweight cement mortars: Advantages and inconveniences of expanded perlite and its influence on fresh and hardened state and durability. Construction and Building Materials. https://doi.org/10.1016/j.conbuildmat.2007.05.006

Lee, H. S., Lee, J. Y., \& Yu, M. Y. (2003). Influence of iron oxide pigments on the properties of concrete interlocking blocks. Cement and Concrete Research. https://doi.org/10.1016/S0008-8846(03)00209-6

Liu, K., Wu, Y. F., \& Jiang, X. L. (2008). Shear strength of concrete filled glass fiber reinforced gypsum walls. Materials and Structures/Materiaux et Constructions. https://doi.org/10.1617/s11527-007-9271-8

Li, M., Wu, Z., \& Chen, M. (2011). Preparation and properties of gypsum-based heat storage and preservation material. Energy and Buildings. https://doi.org/10.1016/j.enbuild.2011.05.016

Mármol, I., Ballester, P., Cerro, S., Monrós, G., Morales, J., \& Sánchez, L. (2010). Use of granite sludge wastes for the production of coloured cement-based mortars. Cement and Concrete Composites. https://doi.org/10.1016/j.cemconcomp.2010.06.003

Mazloom, M., Ramezanianpour, A. A., \& Brooks, J. J. (2004). Effect of silica fume on mechanical properties of high-strength concrete. Cement and Concrete Composites. https://doi.org/10.1016/S0958-9465(03)00017-9.

Murat, M., \& Attari, A. (1991). Modification of some physical properties of gypsum plaster by addition of clay minerals. Cement and Concrete Research. https://doi.org/10.1016/0008-8846(91)90019-E.

Mohandesi, J. A., Sangghaleh, A., Nazari, A., \& Pourjavad, N. (2011). Analytical modeling of strength in randomly oriented PP and PPTA short fiber reinforced gypsum composites. Computational Materials Science. https://doi.org/10.1016/j.commatsci.2010.12.020.

Nassif, A. Y., Yoshitake, I., \& Allam, A. (2014). Full-scale fire testing and numerical modelling of the transient thermo-mechanical behaviour of steel-stud gypsum board partition walls. Construction and Building Materials. https://doi.org/10.1016/j.conbuildmat.2014.02.027

Pellegrino, S. (1990). Analysis of prestressed mechanisms. International Journal of Solids and Structures. https://doi.org/10.1016/0020-7683(90)90082-7

Portland Cement. KSCE Journal of Civil Engineering. https://doi.org/10.1007/s12205-014-0452-Z

Prasad, A. M., Menon, D., \& Janardhana, M. (2008). Glass Fibre Reinforced Gypsum wall panels with concrete infill - Research and Construction. Proceedings of the 2nd International Conference on Advances in Concrete and Construction.

Ravi Kumar, C. M., Kumar, A., Prashanth, M. H., \& Reddy, D. V. (2012). Experimental studies on Iron-ore tailing based interlocking paver blocks. International Journal of Earth Sciences and Engineering.

Różycka, A., \& Pichór, W. (2016). Effect of perlite waste addition on the properties of autoclaved aerated concrete. Construction and Building Materials. https://doi.org/10.1016/j.conbuildmat.2016.05.019

Sengul, O., Azizi, S., Karaosmanoglu, F., \& Tasdemir, M. A. (2011). Effect of expanded perlite on the mechanical properties and thermal conductivity of lightweight concrete. Energy and Buildings. https://doi.org/10.1016/j.enbuild.2010.11.008

Serhat Başpinar, M., \& Kahraman, E. (2011). Modifications in the properties of gypsum construction element via addition of expanded macroporous silica granules. Construction and Building Materials. https://doi.org/10.1016/j.conbuildmat.2011.03.022

Sodeyama, K., Sakka, Y., Kamino, Y., \& Seki, H. (1999). Preparation of fine expanded perlite. Journal of Materials Science. https://doi.org/10.1023/A:1004579120164

Sreenivasa, R. L., Menon, D., \& Prasad, A. M. (2008). Prediction of axial compressive strength of Glass Fibre Reinforced Gypsum wall panels. Proceedings of 7th International Conference on Civil and Architecture Engineering ICCAE-7.

Sun, D., \& Wang, L. (2015). Utilization of paraffin/expanded perlite materials to improve mechanical and thermal properties of cement mortar. Construction and Building Materials. https://doi.org/10.1016/j.conbuildmat.2015.10.123

Terai, M., \& Minami, K. (2012). Research and Development on Bamboo Reinforced Concrete Structure. In World Conferences on Earthquake Engineering. https://doi.org/10.1007/s11046-013-9678-4 
Vimmrová, A., Keppert, M., Svoboda, L., \& Černý, R. (2011). Lightweight gypsum composites: Design strategies for multifunctionality. Cement and Concrete Composites. https://doi.org/10.1016/j.cemconcomp.2010.09.011

Wu, Y. F. (2004). The effect of longitudinal reinforcement on the cyclic shear behavior of glass fiber reinforced gypsum wall panels: Tests. Engineering Structures. https://doi.org/10.1016/j.engstruct.2004.06.009

Wu, Y. F., \& Dare, M. P. (2006). Flexural and shear strength of composite lintels in glass-fiber-reinforced gypsum wall constructions. Journal of Materials in Civil Engineering. https://doi.org/10.1061/(ASCE)0899-1561(2006)18:3(415)

Yakovlev, G., Khozin, V., Polyanskikh, I., \& Keriene, J. (2014). Utilization of blast furnace flue dust while modifying gypsum binders with carbon nanostructures. In The 9th International Conference "ENVIRONMENTAL ENGINEERING." https://doi.org/10.3846/enviro.2014.025

Yakovlev, G., Polyanskikh, I., Fedorova, G., Gordina, A., \& Buryanov, A. (2015). Anhydrite and gypsum compositions modified with ultrafine man-made admixtures. In Procedia Engineering. https://doi.org/10.1016/j.proeng.2015.06.195

Zhang, Z., Qiao, F., Wu, D., \& Li, Z. (2012). Uniaxial compression tests research on C35 glazed hollow bead insulation concrete. Applied Mechanics and Materials. https://doi.org/10.4028/www.scientific.net/AMM.105-107.1779 